\title{
PEDOGENESIS ON COASTAL TABLELANDS AREA WITH LOW RANGE ALTIMETRY IN PARAÍBA STATE ${ }^{1}$
}

\author{
GIVANILDO ALVES DA SILVA ${ }^{2}$, DANILO DE LIMA CAMÊLO ${ }^{3 *}$, MARCELO METRI CORRÊA ${ }^{4}$, \\ VALDOMIRO SEVERINO DE SOUZA JÚNIOR ${ }^{2}$, MATEUS ROSAS RIBEIRO FILHO ${ }^{2}$, JOSÉ COELHO \\ DE ARAÚJO FILHO
}

\begin{abstract}
Small variations of relief may change drainage and runoff and hence promote the formation of sandy surface horizons and hardened subsurface horizons (fragipans and/or duripans) in Coastal Tablelands soils. This study aimed to investigate the pedogenesis on Coastal Tablelands area with low range altimetry in Paraíba state; secondly, we also sought to contribute to the improvement of the Brazilian Soil Classification System (BSCS). Four soil profiles ware described and collected to be submitted to routine physical and chemical analysis, determination of $\mathrm{Fe}, \mathrm{Al}$ and $\mathrm{Si}$ extracted by sulfuric acid digestion, sodium citratebicarbonate-dithionite and acid ammonium oxalate, sodium pyrophosphate, and mineralogical analysis in the sand and clay fractions by X-ray diffractometry. Optical density of the oxalate extract (ODOE) was also determined; the results were statistically evaluated using the $\mathrm{R}$ software. Microrelief variations conditioning differentiated water flows, along with the sandy texture of the surface horizons (A and E) and the lower coarse sand/fine sand ratio in the subsurface horizon, seem to promote clay accumulation in depth in the Spodosols developed on Coastal Tablelands environments. For this soils, the argilluvic (argissólico) character at the subgroup level of the BSCS should be incorporated. In addition, Al amorphous mineral phases and/or poorly crystalline play an important role in the formation of strongly cemented horizons (duripans) of the Spodosols, as also reported by other authors. Finally, the ODOE showed to be an efficient indicator of soils under podzolization process, being possible its use as a taxonomic criterion for classification of Spodosols by the BSCS.
\end{abstract}

Keywords: Podzolization. Barreiras Formation. Kaolinite. Cemented Horizons.

\section{PEDOGÊNESE EM ÁREA DE TABULEIROS COSTEIROS COM BAIXA AMPLITUDE ALTIMÉTRICA NO ESTADO DA PARAÍBA}

RESUMO - Pequenas variações de relevo influenciam na drenagem e no escoamento superficial, contribuindo para a formação de horizontes superficiais arenosos e subsuperficiais endurecidos (fragipãs e, ou, duripãs) em solos dos Tabuleiros Costeiros. Este trabalho investigou a pedogênese em área de Tabuleiros Costeiros com baixa amplitude altimétrica no Estado da Paraíba; secundariamente, buscamos contribuir para o aprimoramento do Sistema Brasileiro de Classificação de Solos (SiBCS). Quatro perfis de solos foram descritos e coletados para a realização das análises físicas e químicas de rotina, extrações de $\mathrm{Fe}, \mathrm{Si}$ e $\mathrm{Al}$ por digestão sulfúrica, por ditionito-citrato-bicarbonato de sódio, por oxalato ácido de amônio e por pirofosfato de sódio, e as análises mineralógicas das frações areia e argila por difratometria de raios X. A densidade ótica do extrato de oxalato (ODOE) também foi determinada; os resultados obtidos foram estatisticamente avaliados utilizando o programa R. As variações do microrrelevo condicionando fluxos diferenciados de água, juntamente com a textura arenosa dos horizontes superficiais (A e E) e a menor relação areia grossa/areia fina no horizonte subsuperficial, parece favorecer o acúmulo de argila em profundidade nos Espodossolos desenvolvidos no ambiente dos Tabuleiros Costeiros. Para esses solos, o caráter argissólico em nível de subgrupo do SiBCS deveria ser incorporado. Além disso, fases mineralógicas amorfas e, ou, de baixa cristalinidade de Al têm importante participação na formação de horizontes fortemente cimentados (duripãs) dos Espodossolos. Finalmente, a ODOE mostrou-se eficiente como indicador de solos sob processo de podzolização e poderia ser utilizada como critério taxonômico para classificação de Espodossolos pelo SiBCS.

Palavras-chave: Podzolização. Formação Barreiras. Caulinita. Horizontes Cimentados.

\footnotetext{
"Corresponding author

${ }^{1}$ Received for publication in 10/14/2017; accepted in 12/17/2018

Paper extracted from the independent researches developed by the Postgraduate Program in Soil Science of UFRPE.

${ }^{2}$ Department of Agronomy, Universidade Federal Rural de Pernambuco, Recife, PE, Brazil; givalves@gmail.com - ORCID: 0000-0003-

2496-5977, valdomiro.souzajr@ufrpe.br - ORCID: 0000-0002-1748-4019, mateus.ribeirofo@ufrpe.br - ORCID: 0000-0002-5075-7998.

${ }^{3}$ Department of Agronomy, Universidade Federal do Espírito Santo, Alegre, ES, Brazil; dlcamelosoil@gmail.com - ORCID: 0000-00029801-8772.

${ }^{4}$ Academic Unit of Garanhuns, Universidade Federal Rural de Pernambuco, Garanhuns, PE, Brazil; marcelometri@yahoo.com - ORCID: 0000-0003-0929-4634.

${ }^{5}$ Research Execution Unit, Embrapa Solos, Recife, PE, Brazil; jose.coelho@embrapa.br - ORCID: 0000-0002-8318-7418.
} 


\section{INTRODUCTION}

Coastal Tablelands are distributed along the coast of Brazil, from Rio de Janeiro to Amapá, and are formed predominantly by plain surfaces usually interspersed by deep valleys. These plains are associated with the sediments of the Barreiras Formation, dating from the Tertiary, and occupy approximately 200,000 $\mathrm{km}^{2}$ (CARVALHO et al., 2013; CORRÊA et al., 2008; FILIZOLA et al., 2001). Coastal Tablelands are usually composed of strongly weathered, clayey, sandy-clayey, or sandy soils that are predominantly kaolinitic and iron-poor. Plains containing sandy sediments predominate in the states of Paraíba and Rio Grande do Norte (CORRÊA et al., 2008).

In the northeast region, Coastal Tablelands occupy an area of approximately 10,000,000 ha, corresponding to approximately $16 \%$ of the territory occupied by the states of Bahia, Sergipe, Alagoas, Pernambuco, Paraíba, Rio Grande do Norte, and Ceará (LIMA NETO et al., 2009). Considering the proximity to large urban centers, these plains are of high socioeconomic importance because they are used for cultivating sugarcane and other crops. The states of Alagoas, Pernambuco, Paraíba, and Rio Grande do Norte are used primarily for planting sugarcane (LIMA NETO et al., 2009).

The predominant soils in Coastal Tablelands are Yellow Latosols, Yellow Ultisols, Quartzarenic Neosols and, to a lesser extent, Spodosols, Gray Ultisols, and Plinthosols. The depressions between the plains are formed by Gleysols and, to a lesser extent, by Spodosols and Organosols (NASCIMENTO et al., 2004).

Because of the nature of the parent material (pre-weathered sediments of the Barreiras Formation), the typical soils of Coastal Tablelands are very deep and weathered, and usually well drained. However, small relief variations affect water drainage and surface flow, contributing to the formation of hardened pedogenic horizons, including fragipan (weak cementation) and duripan (strong cementation), which may contain cementing agents such as Fe, $\mathrm{Si}$, and/or Al (CARVALHO et al., 2013; CORRÊA et al., 2015; FILIZOLA et al., 2001; MOREAU et al., 2006). Hardened horizons limit water percolation in depth, limiting water drainage in deeper areas of the landscape. Authors have shown that the spatial variability of the soil chemical attributes and the distribution of granulometric fractions are affected by the water dynamics, which is dictated by the microrelief (OLIVEIRA et al., 2013; SOUZA et al., 2006).

The physical and chemical limitations of these soils warrant implementing adequate land use and management systems. The limitations include the occurrence of cohesive pedogenic horizons, sandy texture, low cation exchange capacity and consequent low natural fertility, and the presence of hardened pedogenic horizons (CORRÊA et al., 2008, 2015; LIMA NETO et al., 2009).

Yellow or Gray Ultisols and Spodosols are common in the Coastal Tablelands of the state of Paraíba, particularly in the north of the municipality of João Pessoa (BRASIL, 1972; COELHO et al., 2017). These plains, with a predominance of Atlantic Forest vegetation (IBGE, 2012), are poorly studied, and the yield of sugarcane, which occupies most of the agricultural areas of Paraíba, is low. The objective of this study was to investigate the pedogenesis in Coastal Tablelands with a small altitude range in an Ultisol-Spodosol transition to adequately guide management practices to optimize crop production in this geomorphological domain in Paraíba state. The second objective is to improve the Brazilian Soil Classification System (BSCS).

\section{MATERIAL AND METHODS}

The study was carried out in an area located in the municipality of Rio Tinto, state of Paraíba, northeast Brazil, in the Atlantic Forest biome (Figure 1 ). The relief varies from flat to smooth undulating with an altitude range from 57 to $63 \mathrm{~m}$ above sea level (a.s.1.).

According to Köppen's classification, the climate of the region is As', tropical rainy with dry summer and a rainy season from March to September (ALVARES et al., 2013). The average annual rainfall is $1,635 \mathrm{~mm}$; the wettest months are April, May, and June, the driest months are October, November, and December, and the mean annual temperature is $25{ }^{\circ} \mathrm{C}$. The primary vegetation is dense ombrophilous forest, with segments of seasonal semideciduous forest, and Restinga, which was almost completely replaced by sugarcane crops, except for preservation and legal reserve areas (IBGE, 2012). The area is inserted in the Coastal Tablelands domain and is dominated by sediments of the Barreiras Formation, with a predominance of strongly weathered, clayey, clayey-sandy, or sandy soils of Cenozoic origin, typically kaolinitic and iron -poor. Sediment thickness varies according to the undulations of crystalline rocks (granites and biotite and/or garnet-hornblende gneisses of the Paraíba do Sul Complex, Precambrian), which are occasionally outcropped, leading to variations in relief forms (SCHOBBENHAUS et al., 1995). 

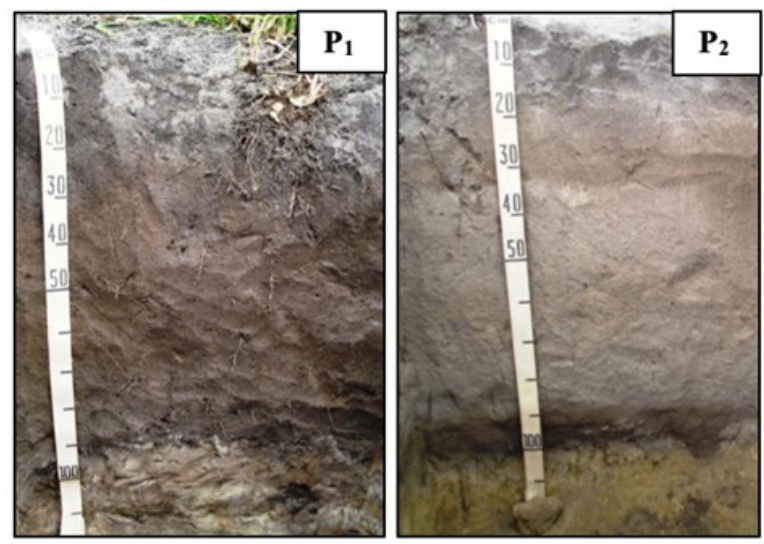

$35^{\circ} 0^{\circ} 30^{\circ \mathrm{W} W} \quad 35^{\circ} 0^{\circ} 0^{\circ} \mathrm{WW}$
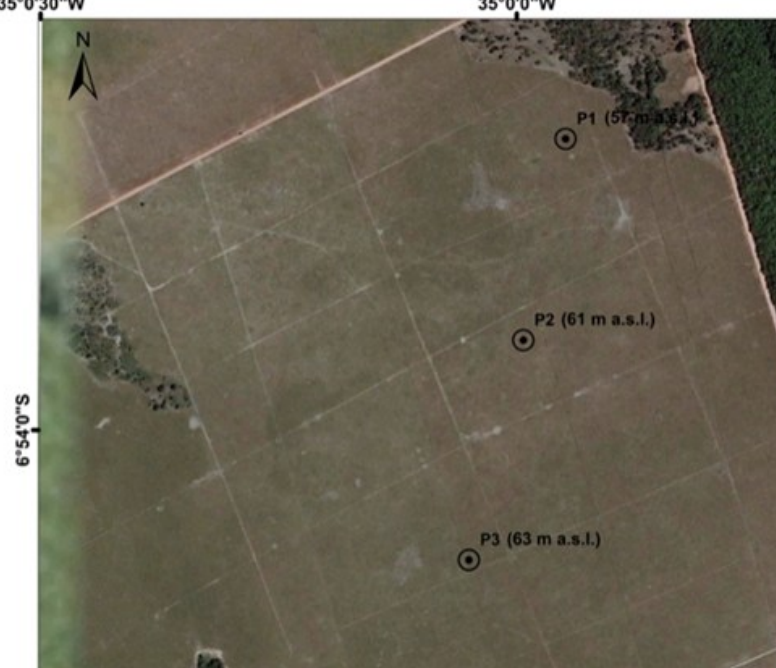
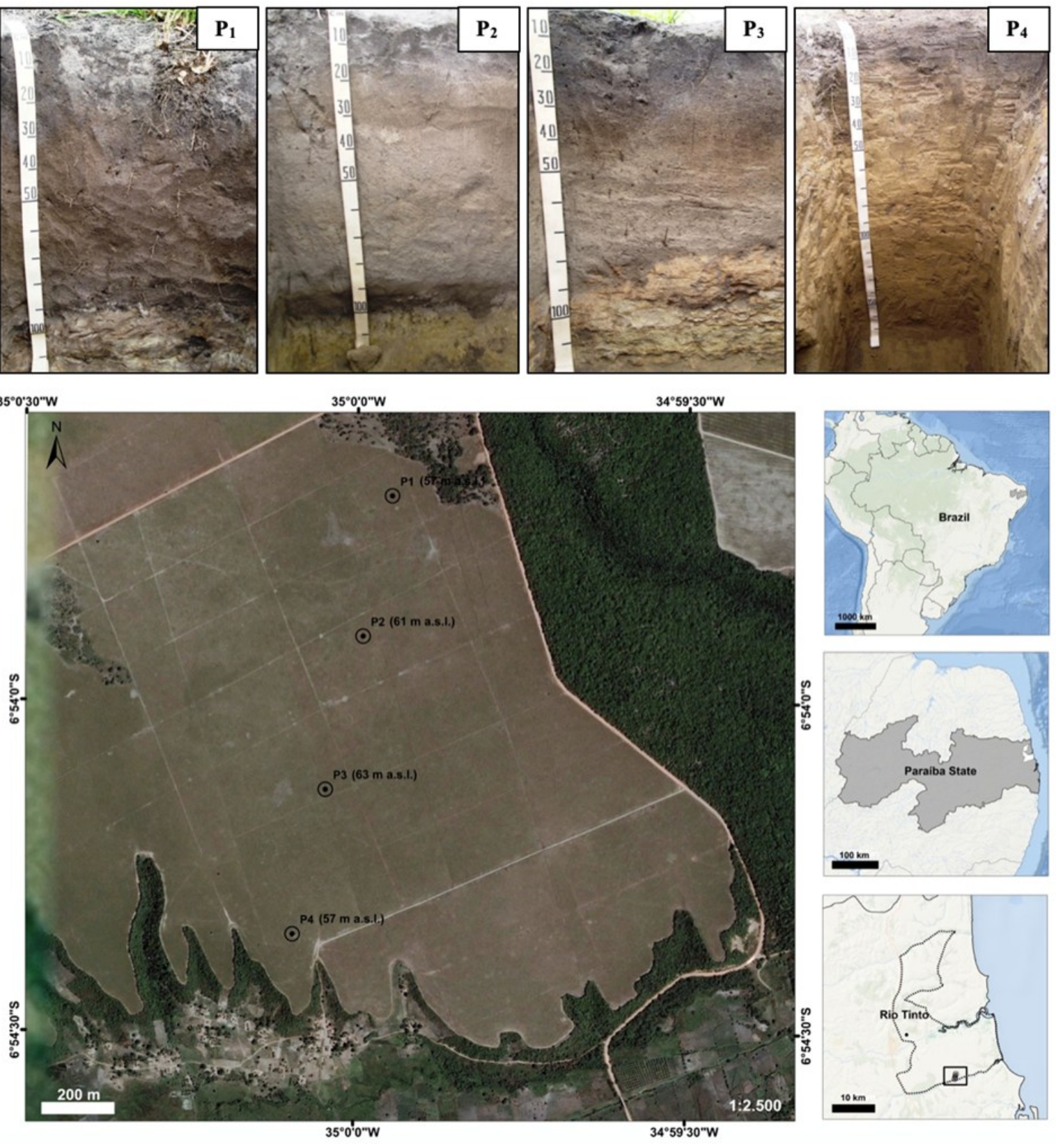

$35^{\circ} 0^{\circ} 0^{\prime \prime W}$
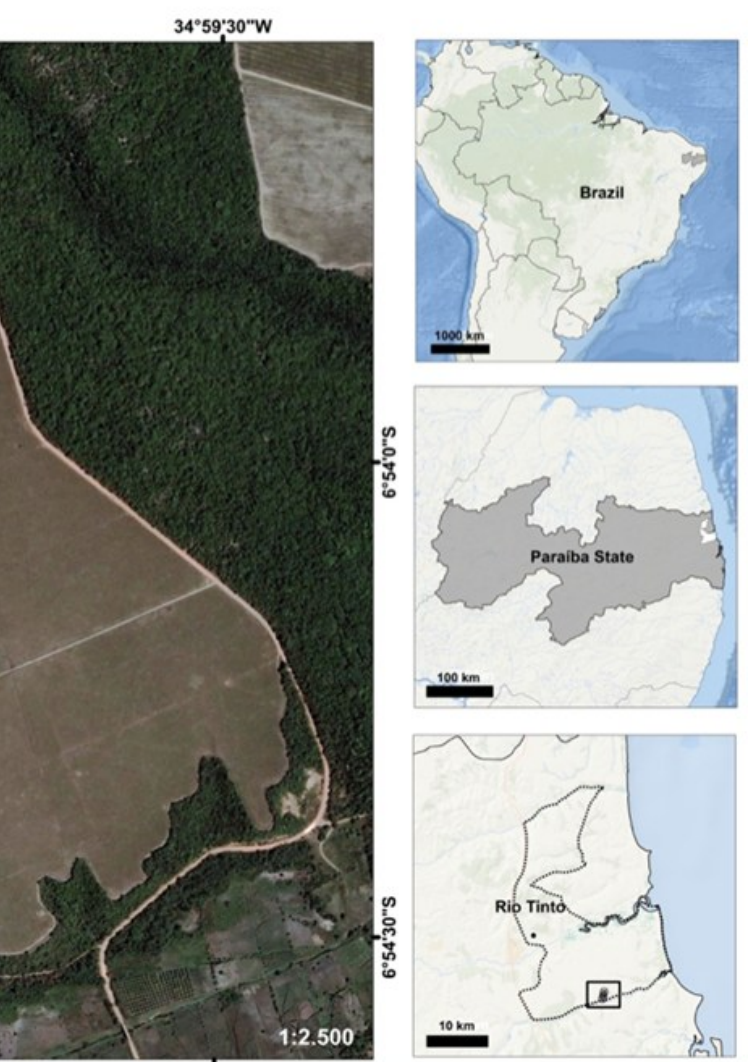

Figure 1. Studied soil profiles and sampling sites.

On the basis of cartographic data obtained by a detailed soil survey performed in the study area, four soil profiles were selected in an UltisolSpodosol transition area with a small altitude range. The trenches were opened at four landscape positions, including coastal tableland depression $\left(\mathrm{P}_{1}\right.$, $57 \mathrm{~m}$ a.s.l.), gentle slope of depression $\left(\mathrm{P}_{2}, 61 \mathrm{~m}\right.$ a.s.l.), flat top $\left(\mathrm{P}_{3}, 63 \mathrm{~m}\right.$ a.s.l.), and middle third of slope $\left(\mathrm{P}_{4}, 57 \mathrm{~m}\right.$ a.s.l.) (Figure 1). The morphological description (color, structure, and consistency) of the profiles was made according to the recommendations of Santos et al. (2015). After that, the deformed and undeformed samples were collected in each horizon for analyzing physical, chemical, and mineralogical characteristics. The soils were classified according to the BSCS (SANTOS et al., 2018).
The air-dried fine earth (ADFE) samples were subjected to granulometric analysis by the densitometric method and determination of soil density (Ds) using the volumetric ring method (TEIXEIRA et al., 2017). The chemical analyses included $\mathrm{pH}$ in water (ratio 1: 2.5); potential acidity in a $1 \mathrm{~mol} \mathrm{~L}^{-1}$ calcium acetate solution; $\mathrm{Na}$ and $\mathrm{K}$ extracted using Mehlich-1 extractant and measured by flame photometry; exchangeable $\mathrm{Ca}, \mathrm{Mg}$, and $\mathrm{Al}$ extracted in $1 \mathrm{~mol} \mathrm{~L}^{-1} \mathrm{KCl}$ and measured by atomic absorption spectrophotometry, and total organic carbon (TOC) using the Walkey-Black method (TEIXEIRA et al., 2017). The obtained results allowed calculating the sum of exchangeable bases (SB), cation exchange capacity (CEC), percentage of base saturation $(\mathrm{V} \%)$, and percentage of $\mathrm{Al}$ 
saturation $(\mathrm{m} \%)$.

In addition to these chemical analyses, $\mathrm{Fe}, \mathrm{Al}$, and $\mathrm{Si}$ were extracted in the $\mathrm{ADFE}$ by sulfur digestion $\left(\mathrm{Fe}_{\mathrm{s}}, \mathrm{Al}_{\mathrm{s}}\right.$, and $\left.\mathrm{Si}_{\mathrm{s}}\right)$ and quantified by atomic absorption spectrophotometry to determine the weathering index (Ki) (TEIXEIRA et al., 2017). The ADFE samples were subjected to three sequential extractions with sodium citrate-bicarbonatedithionite (d) (MEHRA; JACKSON, 1960), a single extraction with acid ammonium oxalate (o) (McKEAGUE; DAY, 1966), and a single extraction with sodium pyrophosphate (p) (COURCHESNE; TURMEL, 2008). The concentrations of $\mathrm{Fe}\left(\mathrm{Fe}_{\mathrm{d}}\right.$, $\mathrm{Fe}_{\mathrm{o}}$, and $\left.\mathrm{Fe}_{\mathrm{p}}\right), \mathrm{Al}\left(\mathrm{Al}_{\mathrm{d}}, \mathrm{Al}_{\mathrm{o}}\right.$, and $\left.\mathrm{Al} \mathrm{p}_{\mathrm{p}}\right)$, and $\mathrm{Si}\left(\mathrm{Si}_{\mathrm{d}}, \mathrm{Si}_{\mathrm{o}}\right.$, and $\mathrm{Si}_{\mathrm{p}}$ ) in the extracts were measured by atomic absorption spectrophotometry.

The optical density of the oxalate extract (ODOE) was measured by spectrophotometry according to (BURT, 2004). After the reaction time with the soil samples, the acid ammonium oxalate extracts were transferred to glass cuvettes with a cross-sectional area of $1.0 \mathrm{~cm}^{2}$ and read in a visible spectrophotometer model BIOESPECTRO SP-22 at a wavelength of $430 \mathrm{~nm}$, as recommended by the Keys to Soil Taxonomy for Spodosols (SOIL SURVEY STAFF, 2014).

For mineralogical analyses, the ADFE samples were treated with hydrogen peroxide to remove organic matter and then subjected to separation of the fine sand, coarse sand, silt, and clay fractions (TEIXEIRA et al., 2017). The measurements were made using an X-ray diffractometer model Shimadzu XRD 6000 coupled to a graphite crystal monochromator, with $\mathrm{CuK} \alpha$ radiation at a voltage of $40 \mathrm{kV}$ and current of $20 \mathrm{~mA}$. The scanning range was $5^{\circ}$ to $65^{\circ} 2 \theta$ for the nonoriented samples, and $3^{\circ}$ to $35^{\circ} 2 \theta$ for the samples oriented on a glass slide, all at a recording speed of $1^{\circ} 2 \theta \mathrm{min}^{-1}$. The coarse sand and fine sand fractions were analyzed by light microscopy. The clay fraction was analyzed in non-oriented slides (powder mount) and oriented slides (smear mount). The oriented slides were prepared with the clay fraction after pretreatment for removing $\mathrm{Fe}$ oxides, saturated with $\mathrm{KCl}$, analyzed before heating and after heating at $350{ }^{\circ} \mathrm{C}$ and $550^{\circ} \mathrm{C}$, and analyzed with $\mathrm{MgCl}_{2}$ without heating (TEIXEIRA et al., 2017).

The physical and chemical results of the samples from the horizons of the four soil profiles were evaluated by both basic statistical analysis [regressions and Pearson correlations] and multivariate analysis [principal component analysis (PCA)] using software R.

\section{RESULTS AND DISCUSSION}

\section{Soil morphological properties}

$\mathrm{P}_{1}$ (Spodosol) presented the horizon sequence Ap, E, and spodic B (Table 1), with morphological properties indicative of a significant increase in clay content in the B horizon (Table 2) associated to the accumulation of organic matter (inferred by its dark yellowish brown color) and a high degree of cementation, characterizing a Bsm-type spodic B horizon. The BSCS has not created classifications at lower categorical levels to indicate the significant increase in clay in depth in Spodosols. In this study, the inclusion of argilluvic (argissólico) character at the subgroup level for this soil class is suggested. Therefore, the podzolization process, forming the spodic B horizon, would define the soil class (taxonomic precedence over the textural B horizon) independently of the intensity of textural differentiation and chronology/hierarchy of active pedogenic processes.

$\mathrm{P}_{2}$ (Spodosol) showed the horizon sequence Ap, E, and Bsm (Table 1), and its morphological properties indicated an increase in clay content in the spodic B horizon, with levels slightly higher than those found in $\mathrm{P}_{1}$ (Table 2). The eluvial horizon (E) was thicker, with a sandy texture, conferring a spessarenic (espessarênico) character. The Bsm horizon had a grayish color with strong yellow and brown mottling, indicating the occurrence of oxidation-reduction processes, which are common in Coastal Tablelands soils, especially in those with hardened horizons (fragipan and duripan) (FILIZOLA et al., 2001; MOREAU et al., 2006). 
Table 1. Morphological properties of the soils.

\begin{tabular}{|c|c|c|c|c|c|c|c|c|}
\hline \multirow{2}{*}{ Horiz. } & \multirow{2}{*}{$\begin{array}{l}\text { Depth } \\
\text { (m) }\end{array}$} & \multirow{2}{*}{ Transition $^{(1)}$} & \multicolumn{2}{|c|}{ Munsell Soil Color (moist) } & \multirow{2}{*}{ Structure $^{(3)}$} & \multicolumn{3}{|c|}{ Consistence $^{(4)}$} \\
\hline & & & Soil matrix & Mottle $^{(2)}$ & & Dry & Moist & Wet \\
\hline \multicolumn{9}{|c|}{ Profile 1 (coastal tableland depression) - Duric Arenic Orthic Ferriluvic Spodosol } \\
\hline Ap & $0-0.20$ & $\mathrm{cl}$, wa & $10 \mathrm{YR} 3 / 2$ & - & we, fi, gr/sg & lo & lo & $\mathrm{npl}, \mathrm{nst}$ \\
\hline $\mathrm{E}_{1}$ & $0.20-0.67$ & gr, sm & $10 \mathrm{YR} 4 / 2$ & - & ma-wce & so & vfr & $\mathrm{npl}$, nst \\
\hline $\mathrm{E}_{2}$ & $0.67-0.90$ & gr, wa & $2.5 \mathrm{Y} 5 / 2$ & - & ma-mce & sha & vfr & $\mathrm{npl}$, nst \\
\hline Bsm & $0.90-1.10+$ & - & $2.5 \mathrm{Y} 6 / 4$ & $\begin{array}{c}10 \mathrm{YR} 3 / 4 \\
\text { co, fi-me, dt }\end{array}$ & ma-sce & eha & efm & npl, sst \\
\hline
\end{tabular}

Profile 2 (gentle slope of depression) - Spessarenic Orthic Ferriluvic Spodosol

\begin{tabular}{|c|c|c|c|c|c|c|c|c|}
\hline Ap & $0-0.17$ & cl, wa & $10 \mathrm{YR} 4 / 2$ & - & we, fi, gr / sg & lo-so & lo-vfr & $\mathrm{npl}$, nst \\
\hline $\mathrm{E}_{1}$ & $0.17-0.36$ & $\mathrm{gr}, \mathrm{sm}$ & $10 \mathrm{YR} 5 / 3$ & - & we, fi, gr / sg & so & vfr & $\mathrm{npl}$, nst \\
\hline $\mathrm{E}_{2}$ & $0.36-0.75$ & $\mathrm{di}, \mathrm{sm}$ & 10 YR 5/3 & - & ma-wce & so & vfr & npl, nst \\
\hline $\mathrm{E}_{3}$ & $0.75-1.05$ & $a b$, wa & $10 \mathrm{YR} 5 / 3$ & - & $\begin{array}{c}\text { ma-sce / we, fi, } \\
\text { sb }\end{array}$ & so & vfr & npl, nst \\
\hline Bsm & $1.05-1.10+$ & - & $10 \mathrm{YR} 6 / 3$ & $\begin{array}{c}2.5 \text { YR } 6 / 6 \\
\text { abn, me, dt } \\
7.5 \text { YR } 5 / 8 \\
\text { fe, fi, dt, }\end{array}$ & ma-sce & eha & efm & spl, sst \\
\hline
\end{tabular}

\begin{tabular}{|c|c|c|c|c|c|c|c|c|}
\hline Ap & $0-0.25$ & $a b$, wa & $10 \mathrm{YR} 3 / 2$ & - & $\begin{array}{c}\text { ma-wce / we, fi, } \\
\text { gr }\end{array}$ & so & vfr & npl, nst \\
\hline $\mathrm{E}_{1}$ & $0.25-0.55$ & $\mathrm{gr}, \mathrm{sm}$ & $10 \mathrm{YR} 4 / 3$ & - & ma-wce & so & vfr & $\mathrm{npl}$, nst \\
\hline $\mathrm{E}_{2}$ & $0.55-0.80$ & $\mathrm{ab}$, ir & $10 \mathrm{YR} 5 / 3$ & - & $\begin{array}{c}\text { ma-wce / we, vfi- } \\
\text { fi, sb }\end{array}$ & so & vfr & $\mathrm{npl}$, nst \\
\hline Bsm & $0.8-1.20+$ & - & 10 YR 5/4 & $\begin{array}{l}10 \mathrm{YR} 4 / 6 \\
\text { co, me-cs, dt }\end{array}$ & ma-sce & eha & efm & $\mathrm{npl}$, nst \\
\hline
\end{tabular}

Profile 4 (middle third of slope) - Typical Dystrocohesive Yellow Ultisol

\begin{tabular}{|c|c|c|c|c|c|c|c|c|}
\hline Ap & $0-0.15$ & $\mathrm{cl}$, wa & $10 \mathrm{YR} 3 / 2$ & - & $\begin{array}{c}\text { ma- wce / we, fi, } \\
\text { gr }\end{array}$ & vha & fr & spl, sst \\
\hline $\mathrm{AB}$ & $0.15-0.37$ & gr, sm & $10 \mathrm{YR} 4 / 3$ & - & ma-mce & vha & fr & spl, sst \\
\hline BA & $0.37-0.65$ & gr, sm & $10 \mathrm{YR} 4 / 4$ & - & ma-mce & eha & $\mathrm{fm}$ & spl, sst \\
\hline $\mathrm{Bt}_{1}$ & $0.65-1.05$ & gr, sm & 10 YR 6/6 & - & ma-mce & eha & $\mathrm{fm}$ & $\mathrm{pl}, \mathrm{st}$ \\
\hline $\mathrm{Bt}_{2}$ & $1.05-1.45$ & gr, sm & 10 YR 6/6 & $\begin{array}{l}2.5 \mathrm{YR} 4 / 6 \\
\mathrm{co}, \mathrm{fi}-\mathrm{me}, \mathrm{pr}\end{array}$ & we, fi-me, sb & vha & $\mathrm{fm}$ & $\mathrm{pl}, \mathrm{st}$ \\
\hline $\mathrm{Bt}_{3}$ & $1.45-1.75+$ & - & 10 YR 6/6 & - & we, fi-me, sb & vha & $\mathrm{fm}$ & $\mathrm{pl}, \mathrm{st}$ \\
\hline
\end{tabular}

${ }^{(1)} \mathrm{ab}=$ abrupt, $\mathrm{cl}=$ clear, gr = gradual, $\mathrm{di}=$ diffuse, $\mathrm{sm}=$ smooth, wa $=$ wavy, ir $=$ irregular. ${ }^{(2)} \mathrm{fe}=$ few, co $=$ common, $\mathrm{abn}=$ abundant, $\mathrm{fi}=$ fine, $\mathrm{me}=$ medium, $\mathrm{cs}=$ coarse, $\mathrm{dt}=$ distinct, $\mathrm{pr}=$ prominent. ${ }^{(3)} \mathrm{we}=$ weak, $\mathrm{vfi}=$ very fine, $\mathrm{gr}=$ granular, $\mathrm{sb}=$ subangular blocky, $\mathrm{sg}=$ single grain, $\mathrm{ma}=$ massive, wce $=$ weakly cohesive, mce $=$ moderately cohesive, sce $=$ strongly cohesive. ${ }^{(4)} \mathrm{lo}=$ loose, so $=$ soft, sha $=$ slightly hard, vha = very hard, eha $=$ extremely hard, $v f r=$ very friable, $\mathrm{fr}=$ friable, $\mathrm{fm}=$ firm, $\mathrm{efm}=$ extremely firm, $\mathrm{npl}=$ non-plastic, $\mathrm{spl}=$ slightly plastic, $\mathrm{pl}=$ plastic, $\mathrm{nst}=$ non-sticky, $\mathrm{sst}=$ slightly sticky, $\mathrm{st}=$ sticky.

The $\mathrm{P}_{3}$ (Spodosol) had a horizon sequence similar to that of the other profiles, differing only in the absence of accumulation of the clay fraction in the Bsm horizon (Table 2). The Bsm horizon in this profile presented yellow color a bit more intense with strong brown mottling, indicating poor drainage, but less pronounced than the profiles $\mathrm{P}_{1}$ and $\mathrm{P}_{2}$ probably because of the slope.

$\mathrm{P}_{4}$ (Ultisol) presented the horizon sequence $\mathrm{Ap}, \mathrm{AB}, \mathrm{BA}, \mathrm{Bt}_{1}, \mathrm{Bt}_{2}$, and $\mathrm{Bt}_{3}$ (Table 1), and the morphological properties (color, structure, and consistency) were considerably different from those of other soils, with clayey texture in the subsurface.

The characteristic feature of $\mathrm{P}_{4}$ was the absence of aggregation in the horizons $\mathrm{AB}, \mathrm{BA}$, and $\mathrm{Bt}_{1}$ up to a depth of $1.05 \mathrm{~m}$, resulting in a moderately cohesive massive structure with a wide variation in dry and wet consistency. These characteristics define cohesive soils (SANTOS et al., 2018). Cohesive soils are usually found in Yellow Ultisols and Oxisols in Coastal Tablelands (CORRÊA et al., 2008, 2015; DANTAS et al., 2014; LIMA NETO et al., 2009; MOREAU et al., 2006). Studies reported that these characteristics reduced the vertical flow of water (CORRÊA et al., 2008, 2015; LIMA NETO et al., 2009). However, the proximity to natural drain conditions seems to promote more efficient water drainage than the other studied profiles (Figure 1), 
even when compared to the profile with a similar height in the landscape $\left(\mathrm{P}_{1}\right)$, with a consequent reduction in oxidation-reduction Fe reactions, and formation of hardened horizons (fragipan and duripan).

\section{Soil physical attributes}

The sand, silt, and clay fractions varied in the soils along the studied area, with a decrease in the sand fraction and an increase in the silt and clay fractions in depth, and the highest clay content was found in Ultisol (Table 2). Studies reported that a decrease in the clay fraction in Spodosols, especially in superficial horizons, were due to the destruction of this fraction by strong hydrolysis and acidolysis reactions (CORRÊA et al., 2015; FILIZOLA et al., 2001); however, the podzolization process usually occurs in soils whose parent materials are predominantly sandy. Subsequently, the elements that make up the minerals of the clay fraction migrate as free ions $\left(\mathrm{H}_{4} \mathrm{SiO}_{4}\right)$ or organometallic compounds ( $\mathrm{Al}$ and $\mathrm{Fe}$ - hummus), forming weak and/or strong bonds between the fractions that compose the underlying horizons, resulting in the formation of the spodic B horizon, fragipan, and/or duripan (CORRÊA et al., 2015; MOREAU et al., 2006).

Table 2. Physical and chemical attributes of the soils.

\begin{tabular}{|c|c|c|c|c|c|c|c|c|c|c|c|c|c|c|c|}
\hline \multirow[b]{2}{*}{ Horiz. } & \multicolumn{4}{|c|}{ Sand } & \multirow[b]{2}{*}{ Silt } & \multirow[b]{2}{*}{ Clay } & \multirow[b]{2}{*}{ Ds } & \multirow[b]{2}{*}{$\mathrm{pH}_{\mathrm{H} 2 \mathrm{O}}$} & \multirow[b]{2}{*}{ SB } & \multirow[b]{2}{*}{$\mathrm{Al}^{3+}$} & \multirow[b]{2}{*}{$\mathrm{H}+\mathrm{Al}$} & \multirow[b]{2}{*}{ CEC } & \multirow[b]{2}{*}{ V } & \multirow[b]{2}{*}{$\mathrm{m}$} & \multirow[b]{2}{*}{ TOC } \\
\hline & Coarse & Fine & Total & $\frac{\text { Coarse }}{\text { Fine }}$ & & & & & & & & & & & \\
\hline & \multicolumn{6}{|c|}{ 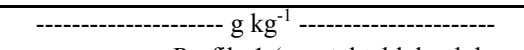 } & $\mathrm{Mg} \mathrm{m}^{-3}$ & \multirow{2}{*}{\multicolumn{5}{|c|}{$\begin{array}{l}\text { aric Arenic Orthic Ferriluvic Spodosol } \\
\text { are }\end{array}$}} & \multirow{2}{*}{\multicolumn{2}{|c|}{---- \% ----- }} & \multirow[t]{2}{*}{$\mathrm{g} \mathrm{kg}^{-1}$} \\
\hline & & & Profile & e 1 (coast & & d denre & sion) -1 & & & & & & & & \\
\hline Ap & 696 & 223 & 919 & 3.12 & 8 & 73 & 1.58 & 5.7 & 2.1 & 0.1 & 4.2 & 6.3 & 33 & 5 & 11.20 \\
\hline $\mathrm{E}_{1}$ & 683 & 247 & 930 & 2.77 & 5 & 65 & 1.50 & 5.7 & 0.4 & 0.2 & 3.7 & 4.1 & 10 & 32 & 5.62 \\
\hline $\mathrm{E}_{2}$ & 626 & 268 & 894 & 2.34 & 30 & 76 & 1.44 & 5.8 & 0.3 & 0.1 & 3.5 & 3.8 & 7 & 27 & 6.19 \\
\hline \multirow[t]{2}{*}{ Bsm } & 415 & 224 & 639 & 1.85 & 186 & 175 & 1.62 & 5.3 & 0.3 & 0.3 & 8.0 & 8.3 & 4 & 51 & 11.95 \\
\hline & \multicolumn{14}{|c|}{ Profile 2 (gentle slope of depression) - Spessarenic Orthic Ferriluvic Spodosol } & \\
\hline Ap & 658 & 265 & 924 & 2.48 & 4 & 72 & 1.65 & 5.8 & 1.2 & 0.0 & 2.1 & 3.3 & 36 & 0 & 6.01 \\
\hline $\mathrm{E}_{1}$ & 643 & 286 & 929 & 2.25 & 6 & 65 & 1.69 & 6.1 & 0.6 & 0.0 & 1.4 & 2.0 & 28 & 0 & 1.54 \\
\hline $\mathrm{E}_{2}$ & 641 & 286 & 927 & 2.24 & 8 & 65 & 1.63 & 6.1 & 0.5 & 0.0 & 1.8 & 2.3 & 22 & 0 & 2.71 \\
\hline $\mathrm{E}_{3}$ & 569 & 312 & 881 & 1.82 & 43 & 76 & 1.56 & 6.0 & 0.4 & 0.0 & 1.9 & 2.3 & 17 & 0 & 1.98 \\
\hline Bsm & 309 & 273 & 582 & 1.13 & 203 & 215 & 1.73 & 5.5 & 0.3 & 0.2 & 7.3 & 7.8 & 4 & 39 & 8.50 \\
\hline \multicolumn{16}{|c|}{ Profile 3 (flat top) - Duric Arenic Orthic Ferriluvic Spodosol } \\
\hline Ap & 570 & 343 & 913 & 1.66 & 14 & 73 & 1.48 & 5.9 & 3.0 & 0.0 & 4.3 & 7.3 & 41 & 0 & 12.06 \\
\hline $\mathrm{E}_{1}$ & 517 & 361 & 878 & 1.43 & 42 & 80 & 1.46 & 5.3 & 0.5 & 0.3 & 6.1 & 6.6 & 7 & 40 & 10.05 \\
\hline $\mathrm{E}_{2}$ & 510 & 355 & 864 & 1.44 & 56 & 80 & 1.50 & 5.4 & 0.6 & 0.2 & 6.1 & 6.7 & 8 & 27 & 10.36 \\
\hline Bsm & 504 & 286 & 790 & 1.76 & 92 & 118 & 1.42 & 5.6 & 1.8 & 0.3 & 11.1 & 12.9 & 14 & 15 & 32.67 \\
\hline \multicolumn{16}{|c|}{ Profile 4 (middle third of slope) - Typical Dystrocohesive Yellow Ultisol } \\
\hline Ap & 472 & 332 & 804 & 1.42 & 56 & 140 & 1.65 & 4.4 & 1.9 & 0.0 & 4.1 & 6.0 & 31 & 0 & 12.81 \\
\hline $\mathrm{AB}$ & 366 & 320 & 686 & 1.14 & 66 & 248 & 1.57 & 4.2 & 1.2 & 0.2 & 4.3 & 5.5 & 22 & 14 & 11.38 \\
\hline BA & 302 & 268 & 570 & 1.13 & 73 & 357 & 1.38 & 4.1 & 0.9 & 0.6 & 4.8 & 5.7 & 16 & 39 & 10.29 \\
\hline $\mathrm{Bt}_{1}$ & 261 & 238 & 499 & 1.10 & 47 & 454 & 1.50 & 4.0 & 0.7 & 0.7 & 3.7 & 4.4 & 17 & 49 & 6.53 \\
\hline $\mathrm{Bt}_{2}$ & 298 & 228 & 526 & 1.30 & 55 & 419 & 1.58 & 4.0 & 0.4 & 0.8 & 3.8 & 4.2 & 09 & 67 & 3.48 \\
\hline $\mathrm{Bt}_{3}$ & 311 & 254 & 565 & 1.23 & 38 & 397 & 1.54 & 4.0 & 0.3 & 0.8 & 2.8 & 3.1 & 10 & 71 & 2.27 \\
\hline
\end{tabular}

Most of the studied Spodosols presented a sandy texture, with the total sand content higher than $864 \mathrm{~g} \mathrm{~kg}^{-1}$ for the surface horizons (A and E); but we highlight an intermediate texture for the spodic $\mathrm{B}$ horizons of the soils $\mathrm{P}_{1}$ and $\mathrm{P}_{2}$ with total sand content equal to 639 and $582 \mathrm{~g} \mathrm{~kg}^{-1}$, respectively (Table 2). The increase in the clay content in the spodic $\mathrm{B}$ horizons of the soils $\mathrm{P}_{1}$ and $\mathrm{P}_{2}$ was sufficiently high to satisfy the $\mathrm{B} / \mathrm{A}$ textural ratio higher than $1.80 \mathrm{~g} \mathrm{~kg}^{-1}$, a criterion established by the BSCS for soils with clay contents less than $150 \mathrm{~g} \mathrm{~kg}^{-1}$ in the A horizon, indicating a conjugated textural $\mathrm{B}$ horizon. However, the argilluvic (argissólico) character is not considered at lower categorical levels in the order of Spodosols by the BSCS (SANTOS et al., 2018).

The effect of microrelief variations on water drainage and surface flow together with the sandy texture of the surface horizons (A and E) seems to favor argilluviation and/or differential erosion of clay (elutriation), with subsequent occurrence of B/A 
textural ratios in Spodosols $\left(\mathrm{P}_{1}\right.$ and $\left.\mathrm{P}_{2}\right)$. Oliveira et al. (2010) analyzed a Spodosol in the south of Bahia with characteristics intermediate to Ultisol and classified it as Argilluvic Orthic Humiluvic Spodosol based on the presence of a spodic B horizon (Bhs) overlying a textural $\mathrm{B}$ horizon $(\mathrm{Bt})$. In Coastal Tablelands, under the influence of the pre-weathered sediments of the Barreiras Formation, the destruction of the clay fraction with the consequent increase in the migration of its constituent elements through the sandy horizons (A and E) and subsequent accumulation of these elements in the clayey subsurface horizon (Bh, Bs, or Bhs) appear to determine the genesis of these Spodosols, as reported by Filizola et al. (2001) and Corrêa et al. (2015). However, we highlight the possibility of occurrence of other processes of textural differentiation (SILVA et al., 2012), considering that the clay fraction was not increased in the spodic $\mathrm{B}$ horizon of the $\mathrm{P}_{3}$ because of the relief condition (flat top). Similarly, Oliveira et al. (2013) emphasized the effect of microrelief on the production of specific water flows along different surface forms (convex, rectilinear, and concave), resulting in significant variations in the distribution of granulometric fractions in Cambisols of limestone origin.

In addition, the coarse sand fraction was much more expressive in all soils except for the Bsm horizons of the soils $\mathrm{P}_{1}$ and $\mathrm{P}_{2}$ and in the $\mathrm{Bt}_{1}$ of the soil $\mathrm{P}_{4}$, where the coarse sand/fine sand ratios were lower. This characteristic may have favored the increase of the clay content in subsurface in the Spodosols, especially by argilluviation and/or elutriation. The retention of the fine particles in the zones whose fine sands is distributed between the porosity of the larger sand grains may result in packaged zones that act as sieves of fine materials transported through the water flows; thus incipient bands are formed representing barriers to water descending movement (DIJKERMAN et al., 1967). Silva et al. (2012) conducted micromorphological studies and confirmed the occurrence of argilluviation (not identified in the field) in Spodosols of the northeast region of Brazil associated with the dominant podzolization process.

The Ds ranged from 1.42 to $1.73 \mathrm{~g} \mathrm{~cm}^{-3}$, and the highest values were observed in hardened horizons (duripans - duric character) in the Spodosols (Table 2), as reported in other studies (CORRÊA et al., 2008; LIMA NETO et al., 2009; MOREAU et al., 2006; OLIVEIRA et al., 2010). The high Ds of duric horizons may be a consequence of the packaging of its components. This hypothesis was confirmed by comparing the granulometry of these horizons with the $\mathrm{Bt}$ horizons of soil $\mathrm{P}_{4}$, with similar composition but lower Ds. This packaging is favored by the lower coarse sand/fine sand ratio of the duripans, leading to higher water retention and accumulation of cementing elements resulting from acidolysis. In $\mathrm{P}_{4}$, the Ds was slightly higher in the surface horizons because of the compaction caused by soil management activities during sugarcane production. In the other horizons, the effect of sandy granulometry on compaction resistance may have been stronger, limiting the degradation caused by management practices.

The principal component analysis of physical variables indicated that the Bsm horizons of the Spodosols $\mathrm{P}_{1}$ and $\mathrm{P}_{2}$ as well as the horizons $\mathrm{Bt}_{1}, \mathrm{Bt}_{2}$, and $\mathrm{Bt}_{3}$ of the Ultisol $\mathrm{P}_{4}$ presented stronger associations with the silt and clay fractions, mainly with the clay fraction because of the longer vector length of this variable (Figure 2). In contrast, the surface horizons (A and E) and the Bsm horizon of Spodosol $\mathrm{P}_{3}$, where the clay content was not increased significantly, had a stronger association with coarse sand, fine sand, and the coarse sand/fine sand ratio. This result confirms the need to consider the argilluvic (argissólico) character at the subgroup level for the taxonomic distinction of Spodosols with marked effect of the clay fraction on the spodic B horizon.

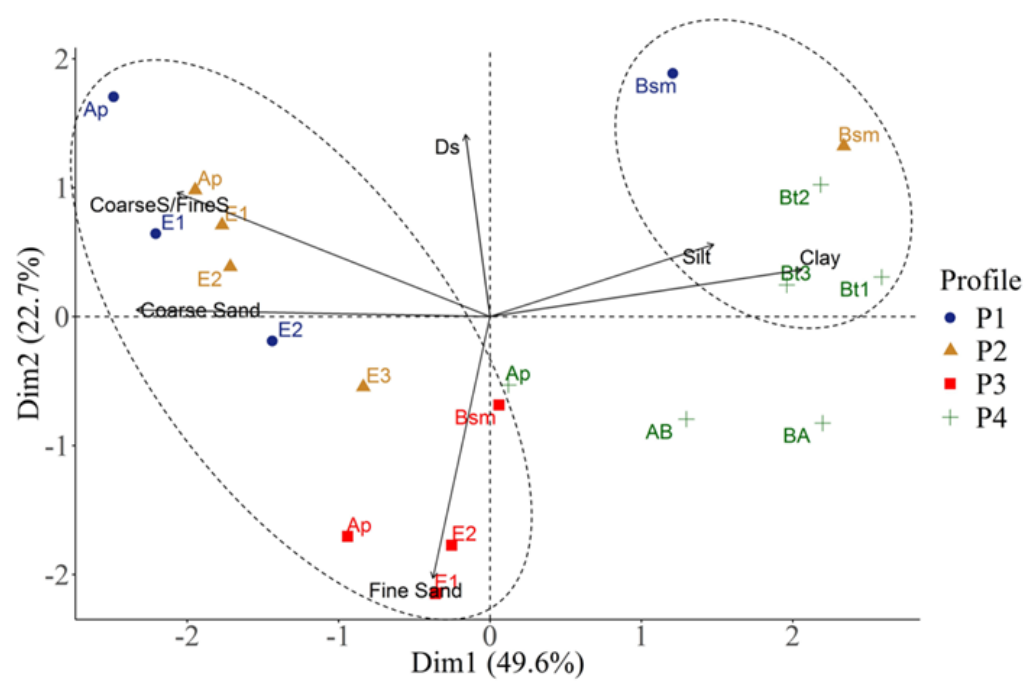

Figure 2. Principal component analysis of the soil physical attributes. CoarseS/FineS $=$ coarse sand/fine sand ratio.

Rev. Caatinga, Mossoró, v. 32, n. 2, p. 458 - 471, abr. - jun., 2019 


\section{Soil chemical attributes}

All studied soils were acidic and dystrophic, and the highest SB values were found in superficial horizons probably because of soil management with correctives and fertilizers during the crop cycles (Table 2). Acidity and dystrophy are due to the fact that these soils are developed from sediments of the Barreiras Formation, with a low reserve of cations and predominance of kaolinite (CORRÊA et al., 2008; DANTAS et al., 2014; LIMA NETO et al. 2009; MOREAU et al., 2006). In addition to the lithogenic effect, pedogenic development is strongly affected by the leaching process in view of the high rainfall in the region.

The CEC values presented a significant correlation $(r=0.93, p<0.01, n=13)$ with the TOC, suggesting that the CEC of the studied soils was predominantly derived from organic matter (Figure $3)$. Similar results were obtained by Corrêa et al. (2008) and Oliveira et al. (2010) for Ultisols and Spodosols originating from sediments of the Barreiras Formation.

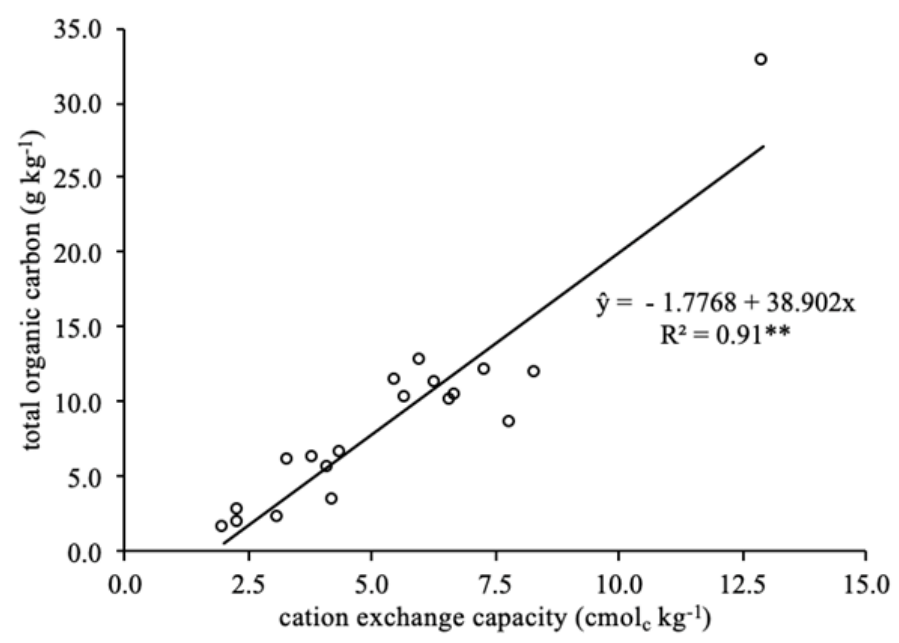

Figure 3. Linear adjustment between the cation exchange capacity and total organic carbon. ${ }^{* *}$ significant at a level of significance of $1 \%$.

The exchangeable aluminum $\left(\mathrm{Al}^{3+}\right)$ of Spodosols was low, varying from 0 to $0.3 \mathrm{cmol}_{\mathrm{c}} \mathrm{kg}^{-1}$, and the highest values were found in the spodic $\mathrm{B}$ horizons (Table 2). Although $\mathrm{Al}^{3+}$ in these horizons is usually complexed with organic compounds, microbial degradation may promote an increase in this element under conditions of better water drainage and aeration (LOPEZ-MAZZETTO et al., 2018; OLIVEIRA et al., 2010). Furthermore, during the extraction of $\mathrm{Al}^{3+}$ with $1 \mathrm{~mol} \mathrm{~L} \mathrm{~L}^{-1} \mathrm{KCl}$, the dissolution of poorly crystalline forms of $\mathrm{Al}$ hydroxides present in these horizons may occur (CUNHA et al., 2015). The highest values were found in Ultisol, with $0.8 \mathrm{cmol}_{\mathrm{c}} \mathrm{kg}^{-1}$ in the horizons $\mathrm{Bt}_{2}$ and $\mathrm{Bt}_{3}$.

The TOC levels ranged from 1.54 to $32.67 \mathrm{~g}$ $\mathrm{kg}^{-1}$, with an increase in depth in Spodosols, indicating carbon illuviation in the subsurface and corroborating the morphological findings obtained in the field. In the Ultisol, the TOC varied from 2.57 and $12.81 \mathrm{~g} \mathrm{~kg}^{-1}$, and the highest values were found in the surface layer. In view of the higher clay content of this soil, there was greater protection of soil organic matter, which limited clay mobility in the profile.

The soils presented a low $\mathrm{Fe}_{\mathrm{s}}$ content $(<50 \mathrm{~g}$ $\mathrm{kg}^{-1}$ ) in all analyzed horizons (Table 3 ), as reported in other studies in soils derived from pre-weathered sediments of the Barreiras Formation (CORREA et al., 2008; LIMA NETO et al., 2009; MOREAU et al., 2006; OLIVEIRA et al., 2010). The Ki index was close to 2.0, indicating that the mineralogical composition of the clay fraction was predominantly kaolinitic, and this result was confirmed by X-ray diffraction analysis. 
Table 3. Sulfuric digestion (s), selective dissolution using sodium citrate-bicarbonate-dithionite (d), acid ammonium oxalate (o), sodium pyrophosphate (p), optical density of the oxalate extract (ODOE), and mineralogical composition of the soils.

\begin{tabular}{|c|c|c|c|c|c|c|c|c|c|c|c|}
\hline \multirow{2}{*}{ Horiz. } & \multicolumn{4}{|c|}{ Sulfuric digestion $^{(1)}$} & \multirow{2}{*}{$\begin{array}{l}\underline{F e}_{o} \\
\mathrm{Fe}_{\mathrm{d}}\end{array}$} & \multirow{2}{*}{$\frac{\mathrm{Al}_{\mathrm{o}}}{\mathrm{Al}_{\mathrm{d}}}$} & \multirow{2}{*}{$\frac{\mathrm{Al}_{\mathrm{o}}}{\mathrm{Al}_{\mathrm{p}}}$} & \multirow{2}{*}{ ODOE } & \multirow{2}{*}{$\begin{array}{c}\mathrm{Al}_{\mathrm{o}}+ \\
0,5 \mathrm{Fe}_{\mathrm{o}}\end{array}$} & \multicolumn{2}{|c|}{ Mineralogical composition ${ }^{(3)}$} \\
\hline & $\mathrm{Si}_{\mathrm{s}}$ & $\mathrm{Fe}_{\mathrm{s}}$ & $\mathrm{Al}_{\mathrm{s}}$ & $\mathrm{Ki}^{(2)}$ & & & & & & Clay fraction & Sand fraction \\
\hline \multicolumn{12}{|c|}{------ $\mathrm{g} \mathrm{kg}^{-1}$------- } \\
\hline \multicolumn{12}{|c|}{ Profile 1 (coastal tableland depression) - Duric Arenic Orthic Ferriluvic Spodosol } \\
\hline Ap & n.d. & n.d. & n.d. & n.d. & 0.34 & 0.79 & 0.41 & 0.32 & 0.17 & $\begin{array}{c}\mathrm{K}, \mathrm{An}, \mathrm{Gt}, \mathrm{Fd}, \mathrm{Gb}, \\
\mathrm{Qz}\end{array}$ & $\mathrm{Qz}, \mathrm{Tm}, \mathrm{Zr}$ \\
\hline $\mathrm{E}_{1}$ & n.d. & n.d. & n.d. & n.d. & 1.24 & 0.41 & 0.82 & 0.30 & 0.01 & n.d. & n.d. \\
\hline $\mathrm{E}_{2}$ & n.d. & n.d. & n.d. & n.d. & 1.26 & 0.48 & 0.86 & 0.26 & 0.01 & n.d. & n.d. \\
\hline Bsm & 143.0 & 12.0 & 137.8 & 1.76 & 0.11 & 1.86 & 1.21 & 0.41 & 0.50 & $\mathrm{~K}, \mathrm{An}, \mathrm{Gt}, \mathrm{Gb}, \mathrm{Qz}$ & Qz \\
\hline
\end{tabular}

Profile 2 (gentle slope of depression) - Spessarenic Orthic Ferriluvic Spodosol

$\begin{array}{cccccccccccc}\text { Ap } & \text { n.d. } & \text { n.d. } & \text { n.d. } & \text { n.d. } & 0.04 & 1.00 & 0.36 & 0.26 & 0.11 & \text { K, An, Gt, Fd, Qz } & \text { Qz, Tm, Ilm } \\ \mathrm{E}_{1} & \text { n.d. } & \text { n.d. } & \text { n.d. } & \text { n.d. } & 0.68 & 0.62 & 0.40 & 0.06 & 0.01 & \text { n.d. } & \text { n.d. } \\ \mathrm{E}_{2} & \text { n.d. } & \text { n.d. } & \text { n.d. } & \text { n.d. } & 1.15 & 0.63 & 0.67 & 0.14 & 0.02 & \text { n.d. } & \text { n.d. } \\ \mathrm{E}_{3} & \text { n.d. } & \text { n.d. } & \text { n.d. } & \text { n.d. } & 0.79 & 0.58 & 0.58 & 0.09 & 0.01 & \text { n.d. } & \text { n.d. } \\ \text { Bsm } & 181.0 & 35.5 & 168.4 & 1.82 & 0.00 & 10.39 & 1.86 & 0.26 & 0.74 & \text { K, An, Gt } & \text { Qz }\end{array}$

Profile 3 (flat top) - Duric Arenic Orthic Ferriluvic Spodosol

\begin{tabular}{|c|c|c|c|c|c|c|c|c|c|c|c|}
\hline Ap & n.d. & n.d. & n.d. & n.d. & 0.07 & 2.84 & 0.60 & 0.22 & 0.20 & $\begin{array}{c}\mathrm{K}, \mathrm{An}, \mathrm{Gt}, \mathrm{Fd}, \mathrm{Gb}, \\
\mathrm{Qz}\end{array}$ & $\begin{array}{c}\text { Qz, Tm, Ilm, } \\
\text { Zr }\end{array}$ \\
\hline $\mathrm{E}_{1}$ & n.d. & n.d. & n.d. & n.d. & 0.91 & 0.82 & 0.43 & 0.28 & 0.01 & n.d. & n.d. \\
\hline $\mathrm{E}_{2}$ & n.d. & n.d. & n.d. & n.d. & 1.38 & 0.47 & 0.44 & 0.25 & 0.02 & n.d. & n.d. \\
\hline Bsm & 34.0 & 9.1 & 37.3 & 1.54 & 0.24 & 15.59 & 0.97 & 0.85 & 0.91 & $\mathrm{~K}, \mathrm{An}, \mathrm{Gt}, \mathrm{Gb}, \mathrm{Qz}$ & Qz \\
\hline \multicolumn{12}{|c|}{ Profile 4 (middle third of slope) - Typical Dystrocohesive Yellow Ultisol } \\
\hline Ap & 56.0 & 19.2 & 36.1 & 2.64 & 0.06 & 1.91 & 0.80 & 0.13 & 0.18 & K. An, Gt, Qz & Qz, Tm, Ilm \\
\hline $\mathrm{AB}$ & n.d. & n.d. & n.d. & n.d. & 0.01 & 1.81 & 0.62 & 0.14 & 0.17 & n.d. & n.d. \\
\hline $\mathrm{BA}$ & 152.0 & 26.1 & 136.5 & 1.89 & 0.01 & 1.69 & 0.84 & 0.13 & 0.19 & n.d. & n.d. \\
\hline $\mathrm{Bt}_{1}$ & n.d. & n.d. & n.d. & n.d. & 0.01 & 1.86 & 0.87 & 0.07 & 0.20 & n.d. & n.d. \\
\hline $\mathrm{Bt}_{2}$ & 156.5 & 45.3 & 157.1 & 1.69 & 0.01 & 1.40 & 0.80 & 0.05 & 0.16 & $\mathrm{~K}, \mathrm{An}, \mathrm{Gt}$ & $\mathrm{Qz}$ \\
\hline $\mathrm{Bt}_{3}$ & n.d. & n.d. & n.d. & n.d. & 0.01 & 0.86 & 0.85 & 0.05 & 0.13 & n.d. & n.d. \\
\hline
\end{tabular}

n.d. not determined. ${ }^{(1)} \mathrm{The}_{\mathrm{Si}}, \mathrm{Fe}_{\mathrm{s}}$ e $\mathrm{Al}_{\mathrm{s}}$ contents are expressed in their oxide form $\mathrm{SiO}_{2}, \mathrm{Fe}_{2} \mathrm{O}_{3}$ and $\mathrm{Al}_{2} \mathrm{O}_{3}$. ${ }^{(2)}$ Molar ratio $\mathrm{Si}_{\mathrm{s}} / \mathrm{Al}_{\mathrm{s}} \times 1.7{ }^{(3)} \mathrm{An}=$ anatase, $\mathrm{K}=$ kaolinite, $\mathrm{Gt}=$ goethite, $\mathrm{Fd}=$ feldspar, $\mathrm{Gb}=$ gibbsite, $\mathrm{Ilm}=$ ilmenite, $\mathrm{Qz}=$ quartz, $\mathrm{Tm}$ $=$ tourmaline, $\mathrm{Zr}=$ zircon.

The results obtained from the selective dissolutions indicated significant differences in the distribution of $\mathrm{Fe}, \mathrm{Al}$, and $\mathrm{Si}$ in all profiles (Figure 4). The results in Spodosols evidenced an accumulation of these elements in the spodic B horizons (Bsm), especially of $\mathrm{Al}$ associated with organic compounds $\left(\mathrm{Al}_{\mathrm{p}}\right)$ and poorly crystalline forms $\left(\mathrm{Al}_{0}\right)$, and these characteristics are typical of soils undergoing podzolization process (COELHO et al., 2010a, 2010b; CORRÊA et al., 2008, 2015; MOREAU et al., 2006; OLIVEIRA et al., 2010; SILVA et al., 2013). 

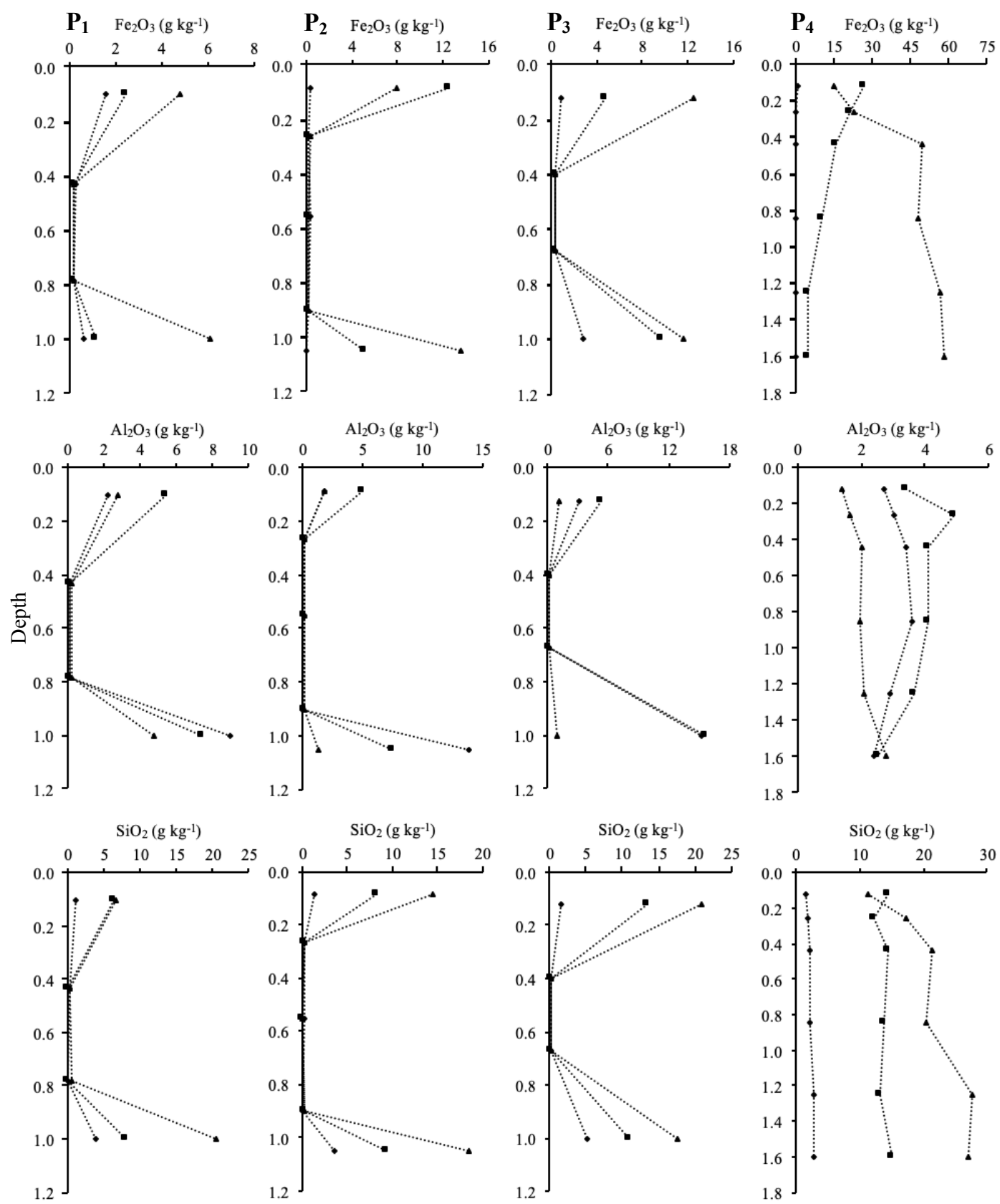

Figure 4. Fe, Al, and Si expressed as oxides, determined by selective dissolution with sodium citrate-bicarbonate-dithionite $(\boldsymbol{\Delta})$, acid ammonium oxalate $(\diamond)$, and sodium pyrophosphate

The high $\mathrm{Al}_{\mathrm{o}} / \mathrm{Al}_{\mathrm{d}}(>1.85)$ and $\mathrm{Al}_{\mathrm{o}} / \mathrm{Al}_{\mathrm{p}}(>$ $0.96)$ ratios demonstrate that the participation of the poorly crystalline forms was higher (Table 3 ), as observed by Coelho et al. (2010a, 2010b) and Silva et al. (2013) in spodic B horizons. In the Ultisol, although the $\mathrm{Al}_{\mathrm{o}} / \mathrm{Al}_{\mathrm{d}}$ ratio was $>1.85$ in the horizons $\mathrm{Ap}$ and $\mathrm{Bt}_{1}$, the dynamics were different, with a trend of equal distribution of the elements in depth. These findings reinforce the hypothesis of the genesis of fragipans and duripans from chemical cementation by $\mathrm{Fe}, \mathrm{Si}$, and/or $\mathrm{Al}$ compounds (CARVALHO et al., 2013; CORREAA et al., 2015; FILIZOLA et al., 2001; MOREAU et al., 2006).

The $\mathrm{Fe}_{\mathrm{d}}$ concentration was less than $20 \mathrm{~g} \mathrm{~kg}^{-1}$ in Spodosols and less than $60 \mathrm{~g} \mathrm{~kg}^{-1}$ in Ultisol (Figure 4), which may be due to the low concentrations of this element in the pre-weathered sediments of the Barreiras Formation on which these soils developed (CORRÊA et al., 2015). The $\mathrm{Fe}_{\mathrm{o}} / \mathrm{Fe}_{\mathrm{d}}$ ratio $>0.06$ clearly separates Spodosols $\left(\mathrm{P}_{1}, \mathrm{P}_{2}\right.$, and $\mathrm{P}_{3}$ ) from Ultisol $\left(\mathrm{P}_{4}\right)$, indicating the considerable participation of poorly crystalline $\mathrm{Fe}$ forms, especially in the eluvial horizons (E) overlying the spodic B horizons with duric character (duripans) that are commonly found in environments with limited drainage (CORRÊA et al., 2008; FILIZOLA et al., 2001). In $\mathrm{P}_{4}$, the $\mathrm{Fe}_{\mathrm{o}} / \mathrm{Fe}_{\mathrm{d}}$ ratio $<0.06$ indicates the predominance of highly crystalline $\mathrm{Fe}$ forms; in 
addition, the higher values found in the Ap horizon corroborates the effect of the organic matter on the inhibition of the crystallinity of Fe oxides.

Except for $\mathrm{P}_{1}$, where the ODOE value in the spodic B horizon was higher than 0.25 but less than double the levels found in eluvial horizons $\left(\mathrm{E}_{1}\right.$ and $\mathrm{E}_{2}$ ), the values of $\mathrm{ODOE}$ and $\mathrm{Al}_{\mathrm{o}}+0.5 \mathrm{Fe}_{\mathrm{o}}$ of the other Spodosols $\left(\mathrm{P}_{2}\right.$ and $\left.\mathrm{P}_{3}\right)$ agreed with the criteria established by the Keys to Soil Taxonomy for defining spodic B horizons (Table 3) (SOIL SURVEY STAFF, 2014). Oliveira et al. (2010) also reported similar results in Spodosols of the Barreiras Formation in the state of Bahia. The BSCS does not use ODOE as a taxonomic criterion for defining
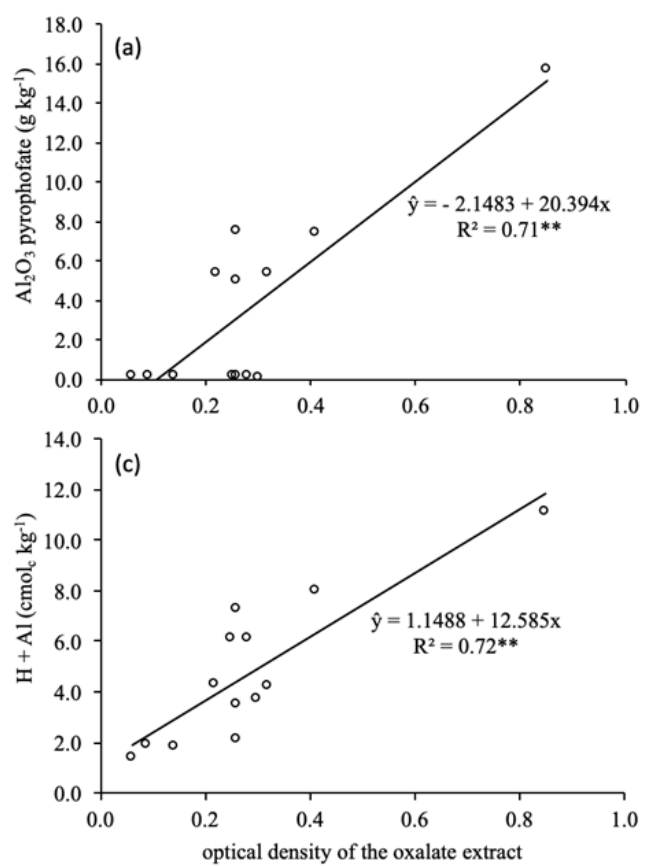

spodic B horizon, but for the other criteria considered (color, carbon content, cementation by organic matter and $\mathrm{Al}$, and the value of $\mathrm{Al}_{\mathrm{o}}+$ $0.5 \mathrm{Fe}_{\mathrm{o}}$ ), the profiles $\mathrm{P}_{1}, \mathrm{P}_{2}$, and $\mathrm{P}_{3}$ have spodic $\mathrm{B}$ horizons and are classified in the order of Spodosols.

The ODOE was also significantly correlated with the $\mathrm{Al}_{\mathrm{p}}(r=0.84, p<0.01, n=13), \mathrm{Al}_{\mathrm{o}}(r=$ $0.71, p<0.01, n=13), \mathrm{H}+\mathrm{Al}(r=0.85, p<0.01, n$ $=13)$, and TOC $(r=0.95, p<0.01, n=13)$ (Figure $5)$, evidencing its importance for identifying soils with significant participation of humic substances, and indicating that this chemical property may be used to assess the occurrence of podzolization process in soils (OLIVEIRA et al., 2010).
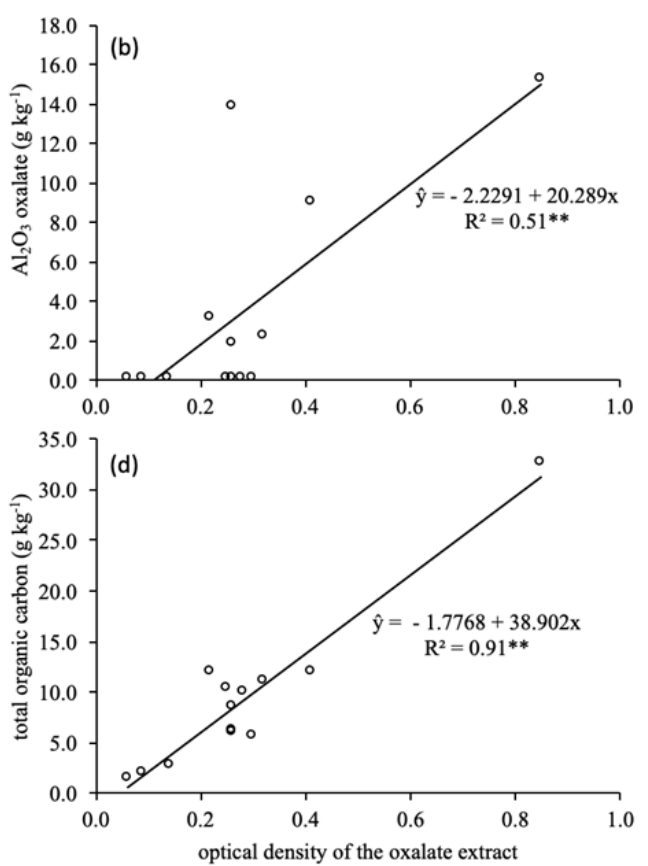

Figure 5. Linear adjustments between the values of optical density of the oxalate extract (ODOE) and the chemical attributes $\mathrm{Al}_{2} \mathrm{O}_{3}$ extracted using sodium pyrophosphate (a) and acid ammonium oxalate (b), potential acidity $(\mathrm{H}+\mathrm{Al})(\mathrm{c})$, and total organic carbon (d). ** significant at a level of significance of $1 \%$.

Similarly, the principal component analysis indicated a strong relationship between the chemical attributes ODOE, TOC, CEC, $\mathrm{Al}_{\mathrm{o}} / \mathrm{Al}_{\mathrm{d}}, \mathrm{Al}_{\mathrm{o}} / \mathrm{Al}_{\mathrm{p}}, \mathrm{Al}_{\mathrm{o}}+$ $0.5 \mathrm{Fe}_{\mathrm{o}}$, and the Bsm horizons of Spodosols (Figure 6). The BSCS (SANTOS et al., 2018), and other studies (COELHO et al., 2010a, 2010b; CORREAA et al., 2008, 2015; MOREAU et al., 2006; OLIVEIRA et al., 2010; SILVA et al., 2013) emphasize the highest levels of $\mathrm{Fe}_{\mathrm{o}}$ and $\mathrm{Al}_{\mathrm{o}}$ in spodic $\mathrm{B}$ horizons. However, the values are highly variable, and hence no quantitative criteria are available to date for defining this horizon. In this study, we highlight the possibility of using ODEO as a taxonomic criterion by the BSCS, as also used by the Keys to Soil Taxonomy to classify Spodosols (SOIL SURVEY STAFF, 2014). Given that it is a spectroscopic measurement, the amplitude of its values is considerably lower than that of the absolute values of $\mathrm{Fe}$ and $\mathrm{Al}$ extracted by acid ammonium oxalate or sodium pyrophosphate (Table 3 and Figure 4).

\section{Soil mineralogical attributes}

The mineralogical assemblage was simple, with a predominance of kaolinite in the clay fraction and quartz in the sand fraction (Table 3 and Figure 7), as also reported in other studies (CARVALHO et al., 2013; CORRÊA et al., 2008; DANTAS et al., 2014; LIMA NETO et al., 2009; MOREAU et al., 2006; OLIVEIRA et al., 2010; SILVA et al., 2012). Quartz, which is usually found in coarse fractions (sand and silt), was also observed in the clay fraction of all studied soils. However, when present in the clay fraction quartz is usually associated with coarse clay particles (SILVA et al., 2012). Carvalho et al. (2013) evidenced the presence of quartz in the clay fraction of Spodosols in the states of Paraíba and Pernambuco. 


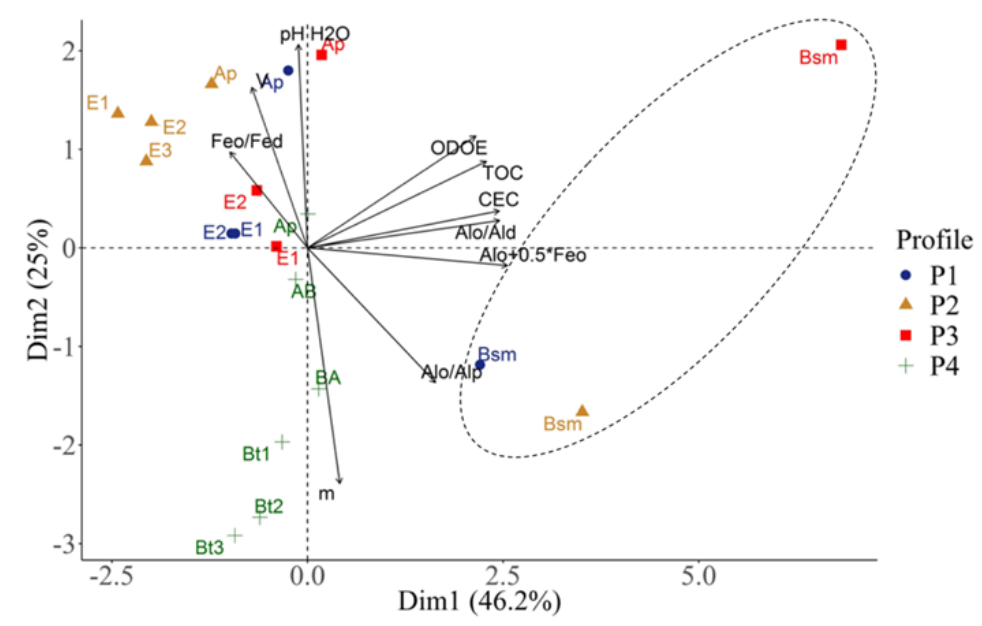

Figure 6. Principal component analysis of the soil chemical attributes.

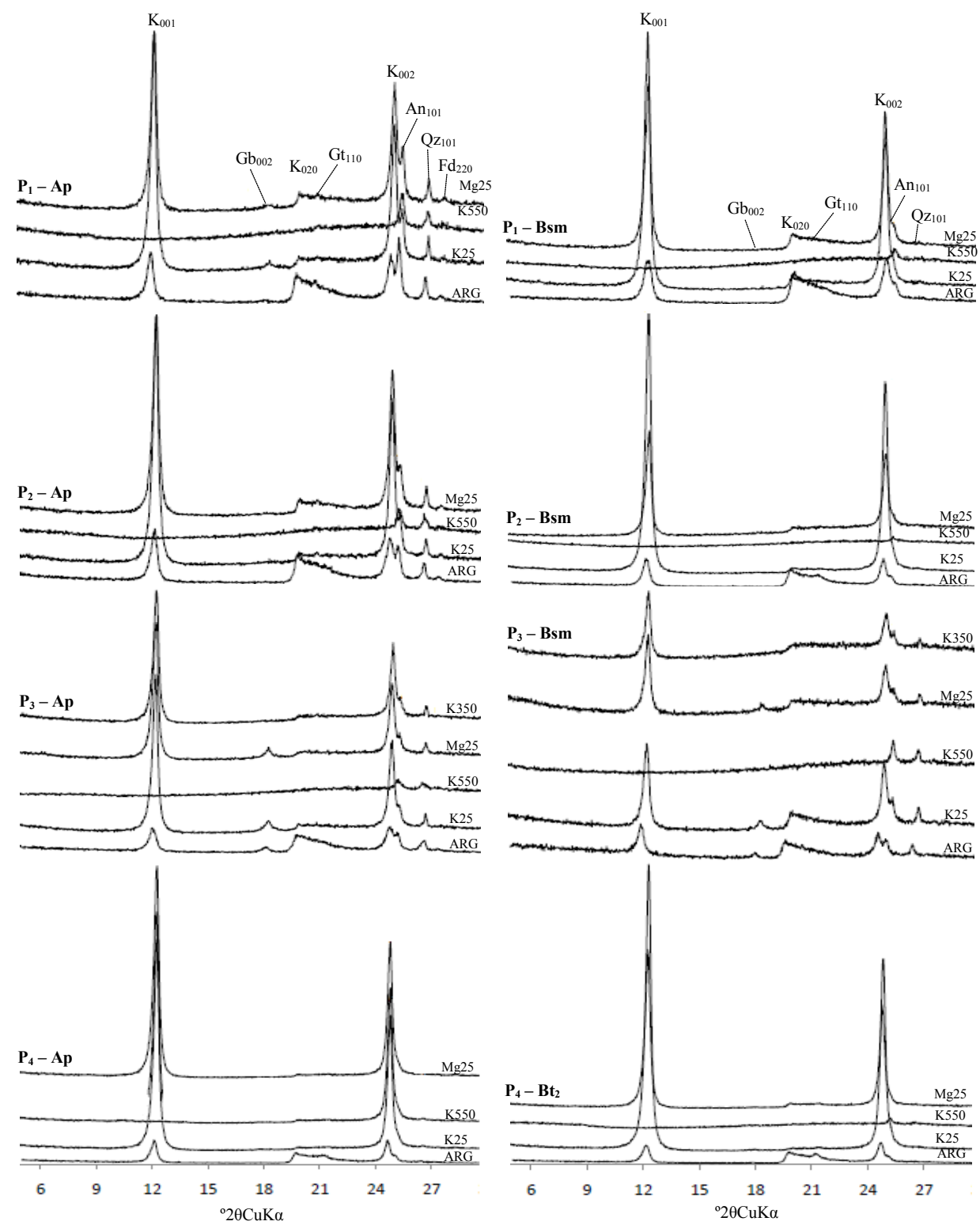

Figure 7. X-ray diffractograms of the clay fraction in the surface and subsurface horizons. ARG = clay without pretreatment, $\mathrm{K} 25$ = clay saturated with $\mathrm{KCl}$ without heating, $\mathrm{K} 350$ = clay saturated with $\mathrm{KCl}$ and heated to $350{ }^{\circ} \mathrm{C}, \mathrm{K} 550$ = clay saturated with $\mathrm{KCl}$ and heated to $550{ }^{\circ} \mathrm{C}, \mathrm{Mg} 25$ = clay saturated with $\mathrm{MgCl}_{2}$ without heating, $\mathrm{K}=$ kaolinite, $\mathrm{Gb}=$ gibbsite, $\mathrm{Gt}=$ goethite, $\mathrm{An}=$ anatase, $\mathrm{Qz}=$ quartz, $\mathrm{Fd}=$ feldspar. 
Trace concentrations of feldspar were found in the clay fraction of Spodosols but were absent in Ultisol (Table 3 and Figure 7). Feldspar is considered the main precursor of kaolinite in soils originating from sediments of the Barreiras Formation (CORRÊA et al., 2008). Goethite and anatase were found in all studied soils (CARVALHO et al., 2013; CORRÊA et al., 2008; OLIVEIRA et al., 2010).

In the top soils $\left(\mathrm{P}_{1}\right.$ and $\left.\mathrm{P}_{3}\right)$, desilication was more intense because of better drainage; therefore, during weathering there might be phases in which $\mathrm{SiO}_{2}$ activity in solution was lower than that required for producing kaolinite, leading to gibbsite precipitation. Although at low concentrations, gibbsite is common in Coastal Tablelands soils (CARVALHO et al., 2013; CORRÊA et al., 2008).

The coarse sand fraction consisted primarily of quartz $(<95 \%)$, less than $3 \%$ of accessory minerals such as ilmenite, tourmaline, and zircon, and typically kaolinitic clay aggregates of gray color. These aggregates were more concentrated in the Bsm horizons of soils $\mathrm{P}_{1}$ and $\mathrm{P}_{2}$, where they reached up to $5 \%$ of the coarse sand fraction. The quartz grains were predominantly hyaline in $\mathrm{P}_{1}$ and $\mathrm{P}_{2}$ and partially covered by a reddish-brown film, which was more abundant in $\mathrm{P}_{4}\left(\mathrm{Fe}_{\mathrm{d}}\right.$ levels of 15 . $58 \mathrm{~g} \mathrm{~kg} \mathrm{k}^{-1}$ ) because of the higher $\mathrm{Fe}$ oxide concentrations in this soil. In addition, there was no significant difference in the mineralogical nature of the fine sand fraction between the soils; however, there was a slight increase in the number of clay aggregates, corresponding to $6 \%, 7 \%$, and $4 \%$ in the spodic $\mathrm{B}$ horizons of soils $\mathrm{P}_{1}, \mathrm{P}_{2}$, and $\mathrm{P}_{3}$, respectively.

\section{CONCLUSIONS}

Microrelief variations conditioning differentiated water flows, along with the sandy texture of the surface horizons (A and E) and the lower coarse sand/fine sand ratio in the subsurface horizon, seem to favor clay accumulation in depth in the Spodosols developed on Coastal Tablelands environments. Therefore, we suggest incorporating argilluvic (argissólico) character at the subgroup level of the Brazilian Soil Classification System (BSCS) to the Spodosols with a B/A textural ratio. In addition, $\mathrm{Al}$ amorphous mineral phases and/or poorly crystalline determine the cementation and genesis of spodic B horizons with duripans (duric character), as evidenced in our study and by other authors, considering the higher levels of extracted $\mathrm{Al}$ by sodium pyrophosphate $\left(\mathrm{Al}_{\mathrm{p}}\right)$ and acid ammonium oxalate $\left(\mathrm{Al}_{\mathrm{o}}\right)$. Furthermore, the optical density of the oxalate extract (ODOE) was an efficient indicator of soils in which podzolization was the main specific process of soil distinction and, therefore, should be considered a criterion for classifying Spodosols by the BSCS.

\section{ACKNOWLEDGMENTS}

We are grateful to Professor Mateus Rosas Ribeiro (in memoriam) and to FACEPE for funding this research (Grant Nos. APQ 1307-5.01/10 and APQ 0144-5.01/13).

\section{REFERENCES}

ALVARES, C. A. et al. Köppen's climate classification map for Brazil. Meteorologische Zeitschrift, v. 22, n. 6, p. 711-728, 2013.

BRASIL. Ministério da Agricultura. Escritório de Pesquisas e Experimentação. Equipe de Pedologia e Fertilidade do Solo. Levantamento exploratório de reconhecimento dos solos do Estado da Paraíba: Interpretação para uso agrícola dos solos do Estado da Paraíba. Rio de Janeiro, RJ: Embrapa Solos, 1972. 683 p. (Boletim Técnico, 15; SUDENE. Série Pedologia, 8).

BURT, R. Soil survey laboratory methods manual. 4. ed. Washington: USDA, NRCS, 2004. 700 p. (Soil Survey Investigations Report, 42).

CARVALHO, V. S. et al. Caracterização de Espodossolos dos Estados da Paraíba e do Pernambuco, Nordeste do Brasil. Revista Brasileira de Ciência Solo, v. 37, n. 6, p. 1454-1463, 2013.

COELHO, M. R. et al. Fracionamento do alumínio por técnicas de dissoluções seletivas em Espodossolos da planície costeira do Estado de São Paulo. Revista Brasileira de Ciência do Solo, v. 34 n. 4. p. 1081-1092, 2010a.

COELHO, M. R. et al. Química e gênese de solos desenvolvidos sob vegetação de restinga no Estado de São Paulo. Revista Brasileira de Ciência do Solo, v. 34, n. 6. p. 1951-1964. 2010b.

COELHO, M. R. et al. Levantamento pedológico detalhado (escala 1:5.000) e estoque de carbono orgânico do solo da Floresta Nacional Restinga de Cabedelo, municípios Cabedelo e João Pessoa, PB. Rio de Janeiro, RJ: Embrapa Solos, 2017. 120 p. (Boletim De Pesquisa e Desenvolvimento, 263).

CORRÊA, M. M. et al. Caracterização física, química, mineralógica e micromorfológica de horizontes coesos e fragipãs de solos vermelhos e amarelos do ambiente Tabuleiros Costeiros. Revista Brasileira de Ciência do Solo, v. 32, n. 1, p. $297-$ 313, 2008

CORRÊA, M. M. et al. Formas de ferro, silício e, ou, alumínio na gênese de fragipãs e horizontes coesos 
dos Tabuleiros Costeiros. Revista Brasileira de Ciência do Solo, v. 39, n. 4, p. 940-949, 2015.

COURCHESNE, F.; TURMEL, M. C. Extractable $\mathrm{Al}, \mathrm{Fe}, \mathrm{Mn}$, and Si. In: CARTER, M. R.; GREGORICH, E. G. (Eds.). Soil sampling and methods of analysis. 2. ed. Boca Raton: CRC Press, 2008. cap. 26, p. 307-316.

CUNHA, G. O. M. et al. Formas de alumínio em solos ácidos brasileiros com teores excepcionalmente altos de $\mathrm{Al}^{3+}$ extraível com $\mathrm{KCl}$. Revista Brasileira de Ciência do Solo, v. 39, n. 5, p. 1362-1377, 2015.

DANTAS, J. S. et al. Gênese de solos coesos do leste maranhense: relação solo-paisagem. Revista Brasileira de Ciência do Solo, v. 38, n. 4, p. 10391050, 2014.

DIJKERMAN, J. C. et al. Properties and genesis of textural subsoil lamellae. Soil Science, v. 104, n. 1, p. 7-16, 1967.

FILIZOLA, H. F. et al. Os fragipãs e duripãs das depressões dos Tabuleiros Costeiros do Nordeste brasileiro: uma proposta de evolução. Revista Brasileira de Ciência do Solo, v. 25, n. 4, p. 947963. 2001.

INSTITUTO BRASILEIRO DE GEOGRAFIA E ESTATÍSTICA - IBGE. Manual Técnico da Vegetação Brasileira. 2. ed. Rio de Janeiro, RJ: CRNEA, 2012. 272 p.

LIMA NETO, J. A. et al. Caracterização e gênese do caráter coeso em Latossolos Amarelos e Argissolos dos tabuleiros costeiros do Estado de Alagoas. Revista Brasileira de Ciência do Solo, v. 33, n. 4, p. 1001-1011, 2009.

LOPEZ-MAZZETTO, J. M. et al. Soil morphology related to hydrology and degradation in tropical coastal podzols (SE Brazil). Catena, v. 162, s/n., p. 1-13, 2018.

McKEAGUE J. A.; DAY, J. H. Dithionite and oxalate - extractable $\mathrm{Fe}$ and $\mathrm{Al}$ as aids in differentiating various classes of soils. Canadian Journal of Soil Science, v. 46, n. 1, p. 13-22, 1966.

MEHRA, J. P.; JACKSON, M. L. Iron oxides removal from soils and clays by a dithionite-citratebicarbonate system buffered with bicarbonate sodium. Clays and Clay Minerals, v. 7, n. 4, p. 317 $-327,1960$. coeso, fragipã e duripã em solos do Tabuleiro Costeiro do Sul da Bahia. Revista Brasileira de Ciência do Solo, v. 30, n. 6, p. 1021-1030, 2006.

NASCIMENTO, G. B. et al. Avaliação de propriedades edáficas em solos de Tabuleiros Costeiros da região Norte do Estado do Rio de Janeiro. Agronomia, v. 38, n. 1, p. 37-44, 2004.

OLIVEIRA, A. P. et al. Spodosols pedogenesis under Barreiras Formation and sandbank environments in the South of Bahia. Revista Brasileira de Ciência do Solo, v. 34, n. 3, p. 847 860, 2010.

OLIVEIRA, D. P. et al. Microrrelevo e a distribuição de frações granulométricas em Cambissolos de origem calcária. Revista Ciência Agronômica, v. 44, n. 4, p. 676-684, 2013.

SANTOS, H. G. et al. Sistema brasileiro de classificação de solos. 5. ed. Brasília, DF: Embrapa, 2018. 356 p.

SANTOS, R. D. et al. Manual de descrição e coleta de solo no campo. 7. ed. Viçosa, MG: Editora Universitária, 2015. 101 p.

SCHOBBENHAUS, C. et al. Mapa geológico do Brasil e da área oceânica adjacente incluindo depósitos minerais (escala 1:2.500.000). 2. ed. Brasília, DF: DNPM, 1995.

SILVA, E. A. et al. Morphology, mineralogy and micromorphology of soils associated to summit depressions of the Northeastern Brazilian Coastal Plains. Ciência Agrotecnologia, v. 36, n. 5, p. $507-$ $517,2012$.

SILVA, E. A. et al. Podzolização em solos de áreas de depressão de topo dos Tabuleiros Costeiros do Nordeste brasileiro. Revista Brasileira de Ciência do Solo, v. 37, n. 1, p. 11-24. 2013.

SOIL SURVEY STAFF. Keys to Soil Taxonomy. 12. ed. Washington: Natural Resources Conservation Service, 2014. 360 p.

SOUZA, Z. M. et al. Small relief shape variations influence spatial variability of soil chemical attributes. Scientia Agricola, v. 63, n. 2, p. 161-168, 2006.

TEIXEIRA, P. C. et al. Manual de métodos de análise de solo. 3. ed. Brasília, DF: Embrapa, 2017. $573 \mathrm{p}$.

MOREAU, A. M. S. S. et al. Gênese de horizonte 